the application of the wave theory to problems in inorganic and organic chemistry. The School was opened by Mr. Michael Tierney, president of University College, Dublin, who referred to the responsibility of the man of science for the uses, good and bad, made of his discoveries.

\section{Physiology and Pathology of Animal Reproduction}

AT the final meeting on June 30 of the first International Congress of the Physiology and Pathology of Animal Reproduction and Artificial Insemination, which was held in Milan under the auspices of the University and of the Spallanzani Institute, a permanent committee was set up to organise within three years from now another congress on the subject. This committee is constituted as follows : J. Anderson (Kenya), Prof. T. Bonadonna (Italy), Prof. E. Garcia Mata (Argentina), Prof. R. M. C. Gunn (Australia), Dr. J. Hammond (Great Britain), Prof. N. Lagerlof (Sweden), Prof. G. Lesbouyries (France), Prof. B. B. Morgan (United States), Prof. E. Sorensen (Denmark). Prof. N. Lagerlof has been elected president and Dr. Hammond and Prof. Sorensen vice-presidents. Prof. T. Bonadonna, of Milan, secretary general of the first Congress, has been appointed secretary of the committee.

\section{Revue Générale du Caoutchouc}

"RubBer Developments" reports that arrange. ments have been made whereby the old-established monthly journal, Revue Généralé du Caoutchouc, can be more readily obtained in Great Britain. Recently, the journal has been improved in make-up, and a welcome feature now is the inclusion of summaries in English of the more important articles. Specimen copies of the journal, subscription forms and further information can be obtained from the Secretary, British Rubber Development Board, Market Buildings, Mark Lane, London, E.C.3.

\section{Earthquakes during March and April, 1948}

THERE were at least nineteen strong earthquakes in the world during March, and at least seven during April. The strongest shock during March was probably that of March 3 from an epicentre near lat. $18^{\circ}$ N., long. $119^{\circ} \mathrm{E}$. off the north-west coast of Luzon, Philippine Islands. It gave ground amplitudes of $160 \mu$ at Kew. The second strongest was on March I, from an epicentre near lat. $3^{\circ}$ S., long. $130 \cdot 5^{\circ} \mathrm{E}$., off the west coast of New Guinea. This gave ground amplitudes of $80 \mu$ at Kew. The deepest shock during March occurred on March 23 from an epicentre near lat. $51^{\circ} \mathrm{N}$., long. $155^{\circ} \mathrm{E}$., off the southern coast of Kamchatka. The depth of focus was between 200 and $250 \mathrm{~km}$. The only great shock on land was on March 27, when a severe earthquake shook the city of Sucre in Bolivia, causing considerable damage to property, including the cathedral, plunging the city into darkness and cutting off communications with the rest of Bolivia ; only three casualties have been reported. An earth tremor on March 16 was felt at Lourdes, Argeles and Bagnères; but no damage is reported. There were no great earthquakes on land during April. The greatest earthquake during April was that on April 21 from an epicentre near lat. $19^{\circ}$ N., long. $69 \cdot 5^{\circ} \mathrm{W}$., off the north-east coast of the Dominican Republic, and the deepest $(200 \mathrm{~km}$.) was on April 12 from an epicentre near lat. $14^{\circ} \mathrm{N}$., long. $90 \cdot 5^{\circ} \mathrm{W}$, off the coast of Guatemala. Reports for these months have been received from the International Bureau at Strasbourg, the Jesuit Seismo- logical Association, the U.S. Coast and Geodetic Survey and the following individual observatories: Cleveland (Ohio), Beograd, De Bilt, Durham, Kew, Stuttgart, Toledo, Uccle, Zurich and the Swiss stations.

\section{Colonial Services: Appointments}

THE following appointments in the Colonial Services have been announced: $R$. Wilcox, inspector of mines, Malaya; L. St. Clair Bartholomew, fisheries officer, Uganda; Miss E. B. Cheek, biochemist, Institute of Medical Research, Malaya; D. H. Constable, soil survey officer, Trinidad; J. Fleming, inspector of plants and produce, Nigeria; Miss R. M. Lowe, fisheries research officer, Uganda; L. J. S. Littlejohn (botanist and plant pathologist, Cyprus), soil conservation officer, Cyprus ; P. O. Wiehe (plant pathologist, Mauritius), plant pathologist, Nyasaland; J. A. N. Burra (assistant conservator of forests, Palestine), assistant conservator of forests, St. Lucia, Windward Islands ; A. B. Walton (senior assistant conservator of forests, Federation of Malaya), conservator of forests, Federation of Malaya ; R. J. S. Waddington (inspector of mines, Tanganyika), senior inspector of mines, Tanganyika; J. W. Loxton (superintendent of surveys, Palestine), staff surveyor, Kenya ; R. W. Crowther (veterinary officer, Nigeria), veterinary officer, Cyprus; C. M. Anderson (livestock officer, Tanganyika), senior livestock officer, Tanganyika; C. J. Buckley (livestock officer, Tanganyika), senior livestock officer, Tanganyika; J. W. T. Holloway (livestock officer, Tanganyika), senior livestock officer, Tanganyika.

The appointment of J. I. Moggridge (Nature, April 24, p. 637) should read "director, Tsetse Control Department, Uganda".

\section{Announcements}

THE Lister Medal for 1948 has been awarded to Prof. Geoffrey Jefferson, professor of neuro-surgery in the University of Manchester, in recognition of his contributions to "knowledge of the functions and structure of the nervous system, made as a Philosophical Biologist, practising Neuro-surgery". Prof Jefferson will deliver the Lister Memorial Lecture in London in June 1949, under the auspices of the Royal College of Surgeons of England. This is the ninth occasion of the award, which is made by a committee representative of the Royal Society, the Royal College of Surgeons of England, the Royal College of Surgeons in Ireland, the University of Edinburgh and the University of Glasgow.

Dr. J. T. EDWARDs, who was invited in 1946 by the Egyptian Government to advise on veterinary education in that country, has been awarded the Order of the Nile (Third Class). Not only was Dr. Edwards able to give valuable service to the veterinary schools, but also he devised measures for combating an outbreak of cattle plague which threatened to become a national disaster.

Prof. W. Srerpinskr, of the University of Warsaw, and Prof. F. Riesz, of the University of Szeged, have been elected Correspondants for the Section of Geometry of the Paris Academy of Sciences.

WE have received from Messrs. Johnson, Matthey and Co., 73-83 Hatton Garden, London, E.C.1, a catalogue of chemical compounds of the precious and other metals. This contains the names of many compounds of rare metals as well as those of commoner elements, and standard metals of high purity for spectrographic work. 